\title{
Sequence change in the HS2-LCR and Gr-globin gene promoter region of sickle cell anemia patients
}

\author{
E.V. Adorno ${ }^{1,2}$, J.P. Moura-Neto ${ }^{2}$, I. Lyra ${ }^{3}$, A. Zanette ${ }^{3}$, L.F.O. Santos ${ }^{1,2}$, M.O. Seixas ${ }^{1,2}$, \\ M.G. Reis ${ }^{1}$ and M.S. Goncalves ${ }^{1,2}$ \\ ${ }^{1}$ Laboratório de Patologia e Biologia Molecular, Centro de Pesquisas Gonçalo Moniz, FIOCRUZ, \\ Salvador, BA, Brasil \\ 2Departamento de Análises Clínicas e Toxicológicas, Faculdade de Farmácia, Universidade Federal da \\ Bahia, Salvador, BA, Brasil \\ ${ }^{3}$ HEMOBA, Fundação de Hematologia e Hemoterapia da Bahia, Salvador, BA, Brasil
}

Correspondence to: M.S. Gonçalves, Laboratório de Patologia e Biologia Molecular, Centro de Pesquisas Gonçalo Moniz, FIOCRUZ, Rua Waldemar Falcão, 121, 40295-001 Salvador, BA, Brasil

E-mail: mari@bahia.fiocruz.br

\begin{abstract}
The fetal hemoglobin ( $\mathrm{HbF}$ ) levels and $\beta^{S}$-globin gene haplotypes of 125 sickle cell anemia patients from Brazil were investigated. We sequenced the $\mathrm{G} \gamma$ - and $\mathrm{A} \gamma$-globin gene promoters and the DNase I-2 hypersensitive sites in the locus control regions (HS2-LCR) of patients with $\mathrm{HbF}$ level disparities as compared to their $\aleph^{\mathrm{S}}$ haplotypes. Sixty-four (51.2\%) patients had CAR/Ben genotype; 36 (28.8\%) Ben/Ben; 18 (14.4\%) CAR/CAR; 2 (1.6\%) CAR/Atypical; 2 (1.6\%) Ben/Cam; 1 (0.8\%) CAR/Cam; $1(0.8 \%)$ CAR/Arab-Indian, and 1 (0.8\%) Sen/Atypical. The HS2-LCR sequence analyses demonstrated a c. $-10.677 \mathrm{G}>\mathrm{A}$ change in patients with the Ben haplotype and high $\mathrm{HbF}$ levels. The $\mathrm{G} \gamma$ gene promoter sequence analyses showed a $\mathrm{C} .-157 \mathrm{~T}>\mathrm{C}$ substitution shared by all patients, and a c.-222_-225del related to the Cam haplotype. These results identify new polymorphisms in the HS2-LCR and G $\gamma$-globin gene promoter. Further studies are required to determine the correlation between $\mathrm{HbF}$ synthesis and the clinical profile of sickle cell anemia patients.
\end{abstract}

Key words: Fetal hemoglobin; Sickle cell anemia; $\aleph^{\mathrm{S}}$-globin gene haplotypes; Locus control region; $\gamma$-globin promoter

Research supported by CNPq (No. 306524/2004-0), FAPESB/SECTI/SESAB/Gestão Saúde (No. 143104005306), FIOCRUZ, MCT/CNPq/MS-SCTIE-DECIT (No. 409800/2006-6).

Received January 5, 2007. Accepted November 19, 2007

Patients with sickle cell anemia (SCA) have a wide spectrum of clinical manifestations, characterized by heterogeneous severity, that are frequently associated with the levels of fetal hemoglobin ( $\mathrm{HbF}$ ) (1). The $\aleph^{S}$-globin gene haplotypes are related to polymorphic restriction enzyme sites distributed throughout the $\aleph^{S}$-globin gene cluster region, and have been associated with specific $\mathrm{HbF}$ levels and the phenotypic diversity presented by SCA patients $(1,2)$. The major $\aleph^{S}$-globin gene haplotypes have been named Benin (Ben), Central African Republic (CAR), Senegal (Sen), Arab-Indian, and Cameroon (Cam), according to their geographical origin and the ethnic groups in which they are frequently found $(2,3)$.

Previous reports have investigated the roles of $\beta^{s}$ haplotypes and $\mathrm{HbF}$ levels as markers of clinical heterogeneity in SCA (2-4). For example, there is a $\mathrm{T}>\mathrm{A}$ variation in the $A \gamma$-globin gene promoter region (-499) that is associated with the Ben haplotype among Sicilian and North American individuals (5). Most patients with the CAR haplotype have very low $\mathrm{HbF}$ levels, often below $5 \%$ of total $\mathrm{HbF}$, while Ben haplotype carriers have intermediate $\mathrm{HbF}$ levels, from 5 to $15 \%$ (4).

Hemoglobin gene switching depends on complex interactions of stage-specific transcription factors, chromo- 
somal gene order, proximity to the globin locus control region (LCR), and erythroid-specific and ubiquitous transacting factors that interact with the promoter regions $(3,6)$. Some mutations in the $\gamma$-globin gene promoter region are associated with increased $\mathrm{HbF}$ synthesis, such as the c. $-158 \mathrm{C}>\mathrm{T}$ polymorphism has been described in the Sen haplotype $(2,3)$. The LCR is characterized by a series of five DNase I-hypersensitive sites (5'-HS1-HS5). Of particular importance is the 5'-HS2-LCR enhancer, which contains a 46-base pair (bp) binding sequence for the NFE2 and AP-1 trans-acting factors. The 5'-HS2-LCR is flanked by multiple cis-acting sequences that modulate enhancer activity, that contain different number of AT-rich sequences and some single-nucleotide polymorphisms $(7,8)$.

Here, we suggest that sequence variations in both the promoter regions for the $\mathrm{G} \gamma$ - and $\mathrm{A} \gamma$-globin genes and the HS2-LCR regions may be important in establishing the $\mathrm{HbF}$ level diversity found among specific $\aleph^{S}$-globin gene haplotypes in SCA patients from Northeastern Brazilian $(9,10)$.

The $\beta^{S}$ haplotypes and $\mathrm{HbF}$ levels of a group of 125 SCA patients from the Blood Center of Bahia, Salvador, BA, Brazil (HEMOBA) were investigated. The study was approved by the Oswaldo Cruz Research Foundation's human research Ethics Committee. The $\aleph^{S}$ haplotypes were identified using polymerase chain reaction and restriction fragment length polymorphism techniques (11). The $\mathrm{HbF}$ levels were estimated using high-performance liquid chromatography (VARIANT I, BIO-RAD, Hercules, $\mathrm{CA}, \mathrm{USA})$. The $\mathrm{G} \gamma$ - and A $\gamma$-globin gene promoters and
HS2-LCR regions $(6,7,12)$ were sequenced in an $A B I$ Prism 3100 DNA Sequencer using Kit BigDye 03 Terminator $^{\mathrm{TM}}$ Sequencing Standards (Applied Biosystems, Foster City, CA, USA) and specific sequencing primers (13).

The frequencies of various $\beta^{S}$ haplotypes in the 125 patients were 64 (51.2\%) with genotype CAR/Ben; 36 (28.8\%) Ben/Ben; 18 (14.4\%) CAR/CAR; 2 (1.6\%) CAR/ Atypical; 2 (1.6\%) Ben/Cam; 1 (0.8\%) CAR/Cam; 1 (0.8\%) CAR/Arab-Indian, and 1 (0.8\%) Sen/Atypical. Among these, 4 CAR/CAR patients had $\mathrm{HbF}$ levels $\geq 10.0 \%, 3$ Ben/Ben patients had $\mathrm{HbF} \leq 5.0 \%, 11 \mathrm{CAR} /$ Ben patients had $\mathrm{HbF}$ $\geq 15.0 \%$, $18 \mathrm{CAR} /$ Ben patients had $\mathrm{HbF} \leq 5.0 \%$, and $2 \mathrm{Cam} /$ Ben patients had $\mathrm{HbF} \geq 15.0 \%$. From this sample group, ten patients presenting a disparity between the level of $\mathrm{HbF}$ and the $\aleph^{S}$ haplotype were selected for sequencing of the $\mathrm{G} \gamma$ - and $\mathrm{A} \gamma$-globin gene promoter and HS2-LCR regions. Two Cam/Ben patients were selected, with $\mathrm{HbF}$ levels of 17.1 and $27.4 \%$. Two Ben/Ben patients were selected, with $\mathrm{HbF}$ levels of 11.5 and $1.3 \%$. Three CAR/ Ben patients were selected, with $\mathrm{HbF}$ levels of 1.2, 10.1, and $17.6 \%$. Two CAR/CAR patients were selected, with $\mathrm{HbF}$ levels of 8.7 and $14.9 \%$. The CAR/Atypical patient was also studied and had an $\mathrm{HbF}$ level of $9.6 \%$. The $\mathrm{HbF}$ levels and clinical characteristics of the ten patients are shown in Table 1.

Sequencing of the $\mathrm{G} \gamma$ - and A $\gamma$-globin gene promoter regions confirmed the presence of specific polymorphisms (14), including c.-533_-532inv (AGA to AAG) and c.-400_ $-395 \mathrm{del}$ in the 5 ' region of the Gy gene, and c.-225_-222del in the $5^{\prime}$ region of the A $\gamma$ gene. We also found a nucleotide

Table 1. Summary of fetal hemoglobin levels $(\mathrm{HbF})$, age, $\aleph^{\mathrm{S}}$-globin gene haplotype and polymorphic cis-acting sequences found among sickle cell anemia patients from Northeast Brazil.

\begin{tabular}{|c|c|c|c|c|c|c|c|c|}
\hline \multirow[t]{2}{*}{ Patient } & \multirow{2}{*}{$\begin{array}{l}\mathrm{HbF} \\
(\%)\end{array}$} & \multirow{2}{*}{$\begin{array}{c}\text { Age } \\
\text { (years) }\end{array}$} & \multirow[t]{2}{*}{ Complications } & \multirow{2}{*}{$\begin{array}{l}\text { Red blood cell } \\
\text { transfusions }\end{array}$} & \multirow{2}{*}{$\begin{array}{c}{ }^{S} \\
\text { haplotype }\end{array}$} & \multirow{2}{*}{$\frac{\text { HS2-LCR }}{-10,677}$} & \multicolumn{2}{|c|}{$\mathrm{G} \gamma$} \\
\hline & & & & & & & $\begin{array}{l}-225 \\
-222\end{array}$ & -157 \\
\hline 1 & $27.4 \%$ & 2 & pneumonia, spleen sequestration, painful crisis & No & Cam/Ben & $\mathrm{G} / \mathrm{A}^{*}$ & $\mathrm{~N} / \mathrm{d}^{*}$ & $\mathrm{C} / \mathrm{C}^{*}$ \\
\hline 2 & $17.1 \%$ & 3 & painful crisis & No & Cam/Ben & $\mathrm{G} / \mathrm{A}^{*}$ & $\mathrm{~N} / \mathrm{d}^{*}$ & $\mathrm{C} / \mathrm{C}^{*}$ \\
\hline 3 & $11.5 \%$ & 45 & leg ulcer, painful crisis & Yes & Ben/Ben & $\mathrm{G} / \mathrm{A}^{*}$ & $\mathrm{~N} / \mathrm{N}$ & $\mathrm{C} / \mathrm{C}^{*}$ \\
\hline 4 & $1.3 \%$ & 21 & leg ulcer & Yes & Ben/Ben & G/G & $\mathrm{N} / \mathrm{N}$ & $\mathrm{C} / \mathrm{C}^{*}$ \\
\hline 5 & $1.2 \%$ & 24 & pneumonia, painful crisis & Yes & CAR/Ben & $\mathrm{G} / \mathrm{G}$ & $\mathrm{N} / \mathrm{N}$ & $\mathrm{C} / \mathrm{C}^{*}$ \\
\hline 6 & $10.1 \%$ & 7 & cerebrovascular accident & Yes & CAR/Ben & $\mathrm{G} / \mathrm{A}^{*}$ & $\mathrm{~N} / \mathrm{N}$ & $\mathrm{C} / \mathrm{C}^{*}$ \\
\hline 7 & $17.6 \%$ & 10 & pneumonia, spleen sequestration & No & CAR/Ben & $\mathrm{G} / \mathrm{A}^{*}$ & $\mathrm{~N} / \mathrm{N}$ & $\mathrm{C} / \mathrm{C}^{*}$ \\
\hline 8 & $8.7 \%$ & 3 & spleen sequestration & Yes & CAR/CAR & $\mathrm{G} / \mathrm{G}$ & $\mathrm{N} / \mathrm{N}$ & $\mathrm{C} / \mathrm{C}^{*}$ \\
\hline 9 & $14.9 \%$ & 26 & - & Yes & CAR/CAR & $\mathrm{G} / \mathrm{G}$ & $\mathrm{N} / \mathrm{N}$ & $\mathrm{C} / \mathrm{C}^{*}$ \\
\hline 10 & $9.6 \%$ & 27 & painful crisis & Yes & CAR/Atypical & $\mathrm{G} / \mathrm{G}$ & $\mathrm{N} / \mathrm{N}$ & $\mathrm{C} / \mathrm{C}^{*}$ \\
\hline
\end{tabular}

Cam = Cameroon; Ben = Benin; CAR = Central African Republic. In Dnase I-2 hypersensitive sites in the locus control regions (HS2$L C R), G / A^{*}=a$ to $A$ substitution and $G / G=$ reference nucleotide in the $-10,677$ position. In the $G \gamma$-globin gene promoter, $d=4-b p$ deletion between -225 and -222 position, $N=$ reference sequence; $C / C^{*}=a T$ to $C$ substitution in the -157 position. ${ }^{*}$ Sequence variations described in patients investigated in the present study. 
substitution at c.-157T>C detected in the G $\gamma$-globin gene promoter (GenBank accession No. bankit 818161, DQ873521; Figure 1), suggesting that this polymorphism, located in the vicinity of another polymorphism (c.-158C > T), is associated with high $\gamma$-globin gene expression $(2,3)$. To confirm this finding, it is necessary to know its distribution in other Afro-descendant populations from Bahia, however.
The Ben/Cam patients presented the c.-222_-225del of the $\mathrm{A} \gamma$-globin gene promoter region, which may be part of a cis-acting element that increases the expression of $\gamma$ globin gene when bound to a specific trans-acting factor (15). Furthermore, the two patients with the Cam haplotype had high $\mathrm{HbF}$ levels, and polymerase chain reaction amplification with primers that were specific and distinct for the

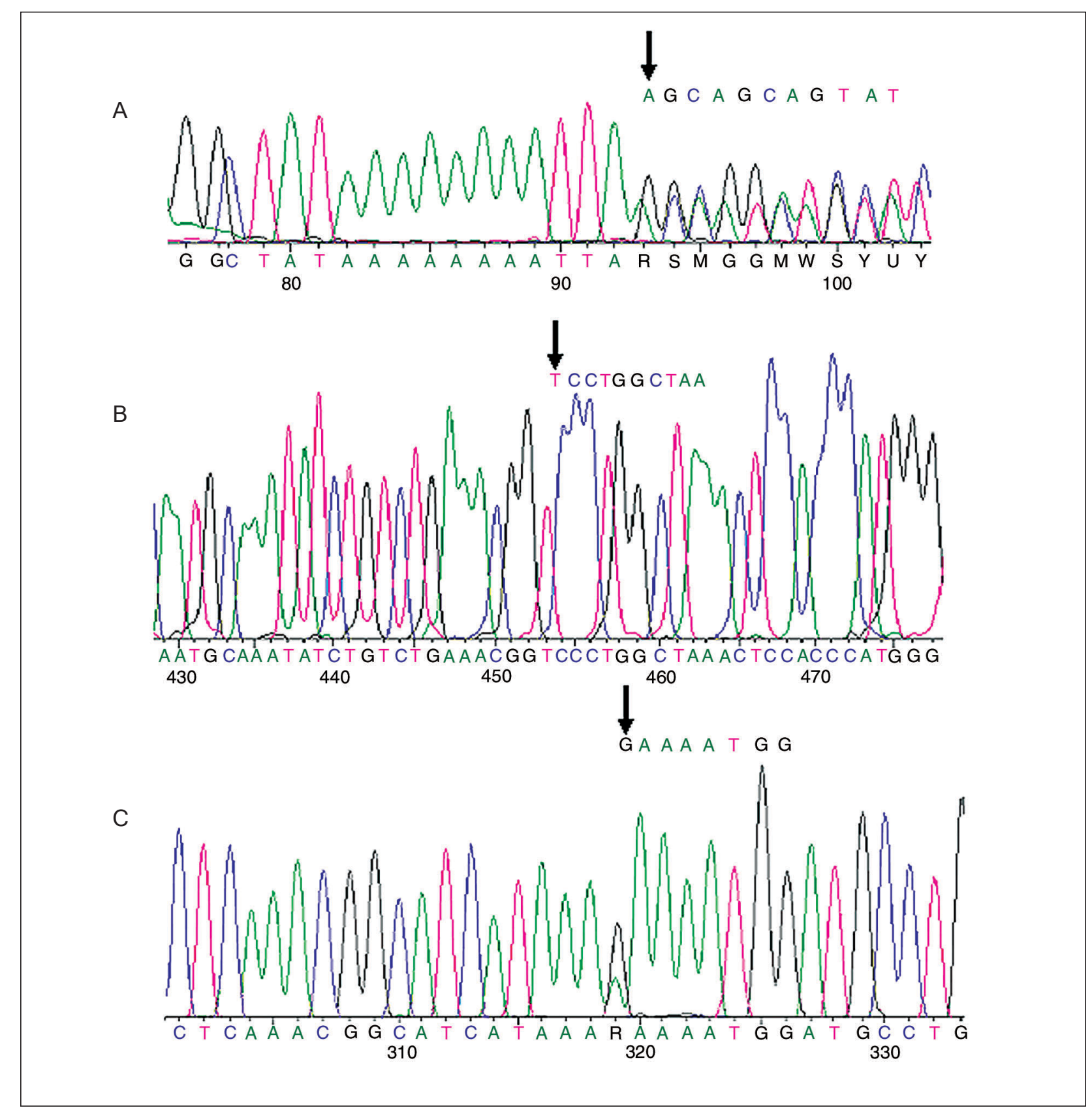

Figure 1. Sequence analysis. $A$, c.-222_-225del of the $\mathrm{G} \gamma$-globin gene promoter region described in the Cam haplotype. $B$, Nucleotide substitution (c.-157T>C) at the G $\gamma$-globin gene promoter found in all patients. $C$, Nucleotide substitution (c.-10.677G $>$ A) outside the core sequences of HS2-LCR found in the Ben haplotype. 
promoter regions of either the $\mathrm{G} \gamma$ - or $\mathrm{A} \gamma$-globin genes demonstrated a similar c.-222_-225del of the G $\gamma$-globin gene (GenBank accession No. bankit 825906, DQ873519; Figure 1).

We detected a $G>A$ substitution outside the core sequences of HS2-LCR (-10.677 position; GenBank accession No. bankit 825964, DQ873522) in 5 SCA patients with the Ben haplotype and high $\mathrm{HbF}$ levels (Figure 1). The $\mathrm{CAR} / \mathrm{Ben}$ and Ben/Ben patients with low $\mathrm{HbF}$ levels did not have this sequence variation. In the small patient group investigated, there were two CAR/CAR patients with high $\mathrm{HbF}$ levels without this $\mathrm{G}>\mathrm{A}$ substitution (Table 1 ), suggesting that this substitution plays an important role in the regulation of $\gamma$-globin gene expression when associated with the Ben haplotype, probably by affecting interaction with a binding site for a specific trans-acting factor. This HS2-LCR sequence change is located close to a binding site for GATA-1 and a ubiquitous trans-acting factor, and can constitute a motif associated with the Ben chromosome (2-4). The other HS2-LCR polymorphisms described here have been related to specific haplotypes in agree-

\section{References}

1. Charache S. Fetal hemoglobin, sickling, and sickle cell disease. Adv Pediatr 1990; 37: 1-31.

2. Nagel RL, Steinberg MH. Genetics of the $S$ gene: origins, genetic epidemiology, and epistasis in sickle cell anemia. In: Steinberg MH, Forget BG, Higgs DR, Nagel RL (Editors), Disorders of hemoglobin: genetics, pathophysiology, and clinical management. New York. Cambridge University Press; 2001. p 711-755.

3. Steinberg $\mathrm{MH}$. Predicting clinical severity in sickle cell anaemia. Br J Haematol 2005; 129: 465-481.

4. Powars D, Hiti A. Sickle cell anemia. Beta s gene cluster haplotypes as genetic markers for severe disease expression. Am J Dis Child 1993; 147: 1197-1202.

5. Patrinos GP, Samperi P, Lo Nigro L, Kollia P, Schiliro G, Papadakis MN. Evidence for the molecular heterogeneity of sickle cell anemia chromosomes bearing the betaS/Benin haplotype. Am J Hematol 2005; 80: 79-80.

6. Tuan D, Kong S, Hu K. Transcription of the hypersensitive site HS2 enhancer in erythroid cells. Proc Natl Acad Sci U S A 1992; 89: 11219-11223.

7. Oner C, Dimovski AJ, Altay C, Gurgey A, Gu YC, Huisman $\mathrm{TH}$, et al. Sequence variations in the 5 ' hypersensitive site-2 of the locus control region of beta $S$ chromosomes are associated with different levels of fetal globin in hemoglobin S homozygotes. Blood 1992; 79: 813-819.

8. Figueiredo MS, Steinberg $\mathrm{MH}$. Fetal hemoglobin in sickle cell anemia: examination of phylogenetically conserved sequences within the locus control region but outside the cores of hypersensitive sites 2 and 3. Blood Cells Mol Dis 1997; 23: 188-200.

9. Adorno EV, Zanette A, Lyra I, Souza CC, Santos LF, ment with previous studies $(7,8)$.

This study confirms the relationship between genotypic heterogeneity and HbF levels in Brazilian SCA patients, emphasizing the high racial admixture of the Bahian Africans population that came from the slave trade from Western Africa, mainly from the Bay of Benin (16). Further studies need to be conducted in the same population in order to clarify the role of new biological markers in the clinical progress of SCA patients, however. The sequence analyses presented herein have identified a new polymorphic site on the promoter region for the $\mathrm{G} \gamma$-globin gene, suggestive of a common sequence characteristic among Brazilian SCA patients. The new sequence variation in the HS2-LCR region may be associated with $\gamma$-globin gene expression.

\section{Acknowledgments}

We are grateful to Fabiola Nascimento Conceição from the Oswaldo Cruz Foundation, Salvador, BA, Brazil, for the English review.
Menezes JF, et al. The beta-globin gene cluster haplotypes in sickle cell anemia patients from Northeast Brazil: a clinical and molecular view. Hemoglobin 2004; 28: 267-271.

10. Goncalves MS, Bomfim GC, Maciel E, Cerqueira I, Lyra I, Zanette A, et al. BetaS-haplotypes in sickle cell anemia patients from Salvador, Bahia, Northeastern Brazil. Braz $J$ Med Biol Res 2003; 36: 1283-1288.

11. Sutton $M$, Bouhassira EE, Nagel RL. Polymerase chain reaction amplification applied to the determination of betalike globin gene cluster haplotypes. Am J Hematol 1989; 32: 66-69.

12. Goncalves MS, Nechtman JF, Figueiredo MS, Kerbauy J, Arruda VR, Sonati MF, et al. Sickle cell disease in a Brazilian population from São Paulo: a study of the beta s haplotypes. Hum Hered 1994; 44: 322-327.

13. Sanger $F$, Nicklen $S$, Coulson AR. DNA sequencing with chain-terminating inhibitors. Proc Natl Acad Sci U S A 1977; 74: 5463-5467.

14. Lanclos KD, Oner C, Dimovski AJ, Gu YC, Huisman TH. Sequence variations in the 5 ' flanking and IVS-II regions of the G gamma- and A gamma-globin genes of beta $\mathrm{S}$ chromosomes with five different haplotypes. Blood 1991; 77: 2488-2496.

15. Lu ZH, Steinberg MH. Fetal hemoglobin in sickle cell anemia: relation to regulatory sequences cis to the beta-globin gene. Multicenter Study of Hydroxyurea. Blood 1996; 87: 1604-1611.

16. Verger P. Flux et reflux de la traite des Nègres entre le Golfe de Benin et Bahia de Todos os Santos. Paris: Mouton Press; 1968. 